IRSH 66 (2021), pp. 93-I I 2 doi:I0.1017/S002085902 I000I 22

(C) The Author(s), 202 I. Published by Cambridge University Press on behalf of the Internationaal Instituut voor Sociale Geschiedenis

\title{
Peasant Resistance in Burkina Faso's Cotton Sector
}

\author{
B ETTINA ENGELS \\ Freie Universität Berlin \\ Otto Subr Institute for Political Sciences \\ Ibnestr.22 \\ I4I95 Berlin, Germany \\ E-mail: bettina.engels@fu-berlin.de
}

ABSTRACT: This article examines how and why smallholder peasants mobilize for collective action to put forward their claims. Taking the resistance by cotton farmers in Burkina Faso as a case study, it demonstrates that institutions of neoliberal governance - which are presented by their proponents as making governance more "effective" by improving the participation of various public and private stakeholders in different degrees - nevertheless fail to represent the interests of the large population of agrarian poor. In the 20Ios, the cotton sector in Burkina Faso became a field of contention, with smallholder cotton producers mobilizing on a massive scale to take collective action. It is argued that the mobilization of cotton farmers can be explained through the effects of the sector's liberalization. Economic liberalization, which has been promoted by the World Bank since the mid-rg9os, has changed the institutional setting of the sector and has significantly impacted the ways and means of collective claim-making available to farmers. Building on primary data (qualitative interviews, focus group discussions, observations) collected during several months of field research between 2018 and 2020, and analyses of press reports and a variety of documents, recent protests by cotton farmers are examined and related to these liberalization policies.

At the mention of protests and uprisings against structural adjustment and liberalization policies, we might think of protests by students and public sector

\footnotetext{
* I am very grateful to all the people in Burkina Faso who shared their knowledge and experience on cotton production with me. In particular, Mohamed Dagano, Brahima Diabaté, Hermann Moussa Konkobo, and Ouiry Sanou supported me with tremendous patience and confidence. Feedback by the participants of the workshop "When 'adjusted' people rebel" in Amsterdam on 29-30 January 2020 is highly appreciated. Leyla Dakhli-Mital and Vincent Bonnecase in particular did a great job of preparing the workshop and providing thorough feedback on the manuscript. Huge thanks also go to Hannah Cross, Kristina Dietz, Elisa Greco, Clare Smedley, and Leo Zeilig.
} 
employees, of the anti-globalization movement and demonstrations against international summits, or of riots related to high food and fuel prices. ${ }^{\mathrm{I}}$ In this article, by contrast, I look at resistance by smallholder peasants, a group often assumed to be less likely to engage in protest. Many scholars suppose that conditions are more favourable for social mobilization and contentious collective action in cities than in rural areas. Consequently, smallholder peasants are, when compared with urban "middle-class" groups and workers, rarely considered as central figures with respect to protests against structural adjustment. This does not mean that peasant resistance against liberalization does not exist; but it seldom features in academic debates, especially in political sciences and sociology, and in many parts of the world it is largely neglected by politicians and social movements. Of course, this does not hold true universally: vibrant rural movements that engage in struggles against liberalization, for example in India, ${ }^{2}$ Mexico, and Brazil, ${ }^{3}$ have become globally famous. Peasants and farmers were a central force in the $\mathrm{N}_{3} \mathrm{O}$ anti-World Trade Organization (WTO) protests in Seattle 1999. ${ }^{4}$ But also beyond these outstanding examples, smallholder peasants in general are by no means mere victims of liberalization and structural adjustment policies. They react in multiple ways: adapting to the conditions and politics; wriggling through them; trying to escape them; or resisting them both individually and collectively. Some even hold "that many of the most visible alternatives to capitalism in the countryside stem from [...] agrarian struggles against neoliberalism". It is argued that the rise of peasant movements in the late twentieth century is not a game of mortal combat played by a doomed-to-die peasantry, but

I. See, for instance, Javier Auyero, “Glocal Riots”, International Sociology, I6: I (200I), pp. 33-53; Silvia Federici and Goerge Caffentzis, "Chronology of African University Students' Struggles: 1985-1998”, in Silvia Federici, George Caffetzis, and Ousseina Alidou (eds), A Thousand Flowers: Social Struggles Against Structural Adjustment in African Universities (Asmara, 2000), pp. I I 5-I 50; Amory Starr, "'(Excepting Barricades Erected to Prevent Us from Peacefully Assembling)': So-called 'Violence' in the Global North Alterglobalization Movement”, Social Movement Studies, 5:1 (2006), pp. 6I-8I; John Walton and David Seddon, Free Markets and Food Riots: The Politics of Global Adjustment (Oxford, 1994).

2. Krishna Murari, "Farmers' Movements in Independent India", Indian Journal of Public Administration, 6r:3 (2015), pp. 457-479.

3. Leandro Vergara-Camus, Land and Freedom: The MST, the Zapatistas and Peasant Alternatives to Neoliberalism (London, 2014).

4. Marc Edelman, "Peasant-Farmer Movements, Third World Peoples, and the Seattle Protests Against the World Trade Organization, I 999”, Dialectical Anthropology, 33:2 (2009), pp. I09-I 28. 5. Kristina Dietz and Bettina Engels, "Radical Transformation: Creating Alternatives to Capitalism in the Countryside", in Haroon Akram-Lodhi, Kristina Dietz, Bettina Engels, and Ben McKay (eds), Handbook on Critical Agrarian Studies (Cheltenham, forthcoming); see Marc Edelman and Wendy Wolford, "Introduction: Critical Agrarian Studies in Theory and Practice", Antipode, 49:4 (2017), pp. 959-976; and Philip McMichael, "Reframing Development: Global Peasant Movements and the New Agrarian Question”, Canadian Journal of Development Studies/Revue canadienne d'études du développement, 27:4 (2006), pp. 47 I-483. 
an indication "of the incompleteness of the transition to capitalism in agriculture". 6

In this article, I examine how and why peasants mobilize for collective action to raise their claims. Taking various forms of resistance by cotton farmers in Burkina Faso as a case study, I demonstrate that institutions of neoliberal governance - presented by their proponents as making governance more "effective" by improving the participation of various public and private stakeholders to multiple scales - nevertheless fail to represent the interests of the large population of agrarian poor.

In the 20Ios, the cotton sector in Burkina Faso became a field of contention, with smallholder cotton producers mobilizing on a massive scale to take collective action. A boycott campaign by cotton farmers - with farmers either refusing to produce cotton or significantly reducing the area they use for cotton cultivation - resulted in an almost thirty per cent decrease in production in 2018-20I9 compared to the previous season. I seek to demonstrate that the mobilization of cotton farmers can be explained through the effects of the sector's liberalization. Liberalization has changed the institutional setting of the sector, and has significantly impacted the ways and means of collective claim-making available to farmers. A core element for such claim-making was the creation in 1998 of a national association of cotton producing cooperatives (Union Nationale des Producteurs de Coton du Burkina Faso or UNPCB). The UNPCB is a typical corporatist institution created according to the logic of liberal, corporate, multistakeholder governance. It aims to rationalize production, though ultimately it functions more to tame and control farmers rather than to represent their interests and help them raise their claims. Consequently, the union itself has become a major point of conflict. It was established in a top-down way by state authorities, hand in hand with the state-owned cotton company SOFITEX and an elite of relatively wealthy farmers, and therefore advances their interests. Such an institution, created in the context of neoliberal policies and economic restructuring, fails to integrate the interests of the majority of cotton producers, who are smallholders; the latter, as a consequence, have had to organize themselves by creating parallel organizations or aligning themselves with other organizations, and they draw on non-institutionalized means of collective action in order to put forward their claims.

The article begins with an explanation of the methodology and data used. This is followed by an outline of the development of the Burkinabé cotton sector, focusing on its institutional framework. This framework changed significantly due to the policies of economic liberalization that have been promoted by the World Bank since the mid-r990s. Subsequently, protests by cotton farmers since the early 2010 s are presented, including a focus on the role of 
the UNPCB. I then explain why the current protests are taking place, and relate them to the liberalization policies.

\section{METHODOLOGY AND DATA}

The empirical material for this case study was collected during five research stays in Burkina Faso, in February-March 2018, February-March and September-October 2019, and February-March and December 2020. In total, I carried out around thirty semi-structured interviews and focus group discussions (FGDs) in Bobo-Dioulasso, Dédougou, Houndé, Ouagadougou, and a few villages in the provinces of Mouhoun (Boucle du Mouhoun region, central-west) and Tuy (Haut-Bassins region, southwest). Interviewees included cotton farmers, workers at the SOFITEX cotton plant, and representatives from labour unions, civil society organizations, cotton companies and the UNPCB. Interviewees were selected to represent a wide range of perspectives on the protests taking place in the cotton sector, including wealthier and poorer farmers, those who have participated in the protests and those who have not. Interviews and FGDs were conducted in French, Mooré, and Dioula (mostly with translation to French). In addition, I had numerous informal conversations, visited the cotton fields, and attended the meetings and mobilization events of the social movements and labour unions.

Secondary sources include reports, mainly from the Burkinabé press, and documents from international organizations (such as the World Bank and the Organisation for Economic Co-operation and Development or OECD), development agencies, state authorities, the cotton industry, trade unions, and non-governmental organizations (NGOs).

Data were analysed through an open coding system, focusing on the various actors' experiences with and perspectives on the effects of the liberalization process, particularly institutional restructuring; the ways in which various interests in the sector are articulated and negotiated; and conflicts and protests, especially the recent boycott campaign.

\section{BURKINA FASO'S COTTON SECTOR}

Cotton production in the former state of Upper Volta (created under colonial rule in I919), nowadays Burkina Faso (as the country has been named since I984), has a long history, going back to the pre-colonial period. In pre-colonial times, cotton was cultivated on a small scale, alongside other crops, for household consumption (to make clothes and blankets) and as a cash crop.? 
Production increased under colonial rule, as the colonial authorities aimed to supply their armies and the workers in the factories of industrializing Europe with cotton clothes. The expansion of African cotton production did not, however, work out as smoothly as planned. The colonial powers did not provide sufficient inputs and infrastructure, nor did they offer attractive purchase prices. ${ }^{8}$ Their efforts to compel farmers to cultivate cotton likewise failed almost completely. ${ }^{9}$

Since the I950s, the sector was developed by the French state-owned cotton company Compagnie Française pour le Développement des Fibres Textiles (CFDT, created in 1949), which went on to take charge of the entire West African CFA franc zone's supply of cotton to the French textile industry.

\section{Nationalization of the cotton sector after decolonialization}

Burkina Faso gained formal independence from French colonial rule in 1960. In 1979, the Burkinabé government nationalized the cotton sector and created the monopolistic company Société Burkinabé des Fibres Textiles (SOFITEX), a joint venture of the government and the CFDT. The sector was (and remains) organized according to a highly vertically integrated filière model. The filière system was set up by CFDT in the I950s and is typical of cotton production in former French colonies in West Africa. It is characterized by state-controlled monopolistic companies such as SOFITEX that organize cotton production. ${ }^{10}$ SOFITEX is in charge of the proliferation and distribution of seeds, fertilizer, and pesticides; it guarantees credits for agricultural inputs for producers; it provides agricultural extensions (i.e. providing education and consultancy services to facilitate the application of research and specialized knowledge to agricultural practices); and it organizes the purchase, transport, ginning, and sale of the grains and fibres. The purchase price is fixed before the season begins so that farmers have some security.

Cultivation itself is done by smallholder peasants, mainly on a family or household basis. Most smallholders own a few hectares; those who are better off may own up to fifty hectares. A small minority of wealthy producers own over 100 hectares, and some even hold over 300 hectares. This does not mean, however, that farmers cultivate cotton on the whole area they hold; most produce cotton (Figure I) on a part of their land and cultivate other crops (such as

8. Thomas J. Bassett, The Peasant Cotton Revolution in West Africa: Côte d'lvoire, I880-1995 (Cambridge, 200I); Allen Isaacman and Richard Robertson, "Cotton, Colonialism, and Social History in Sub-Saharan Africa: Introduction”, in Allen Isaacman and Richard Robertson (eds), Cotton, Colonialism, and Social History in Sub-Saharan Africa (Portsmouth, NH, I 995), pp. I-39. 9. Leslie C. Gray, "Cotton Production in Burkina Faso: International Rhetoric versus Local Realities", in William G. Moseley and Leslie Gray (eds), Hanging by a Thread: Cotton, Globalization, and Poverty in Africa (Athens, OH, 2008), pp. 65-82, p. 69.

Io. Gray, "Cotton Production in Burkina Faso", pp. 833-834. 


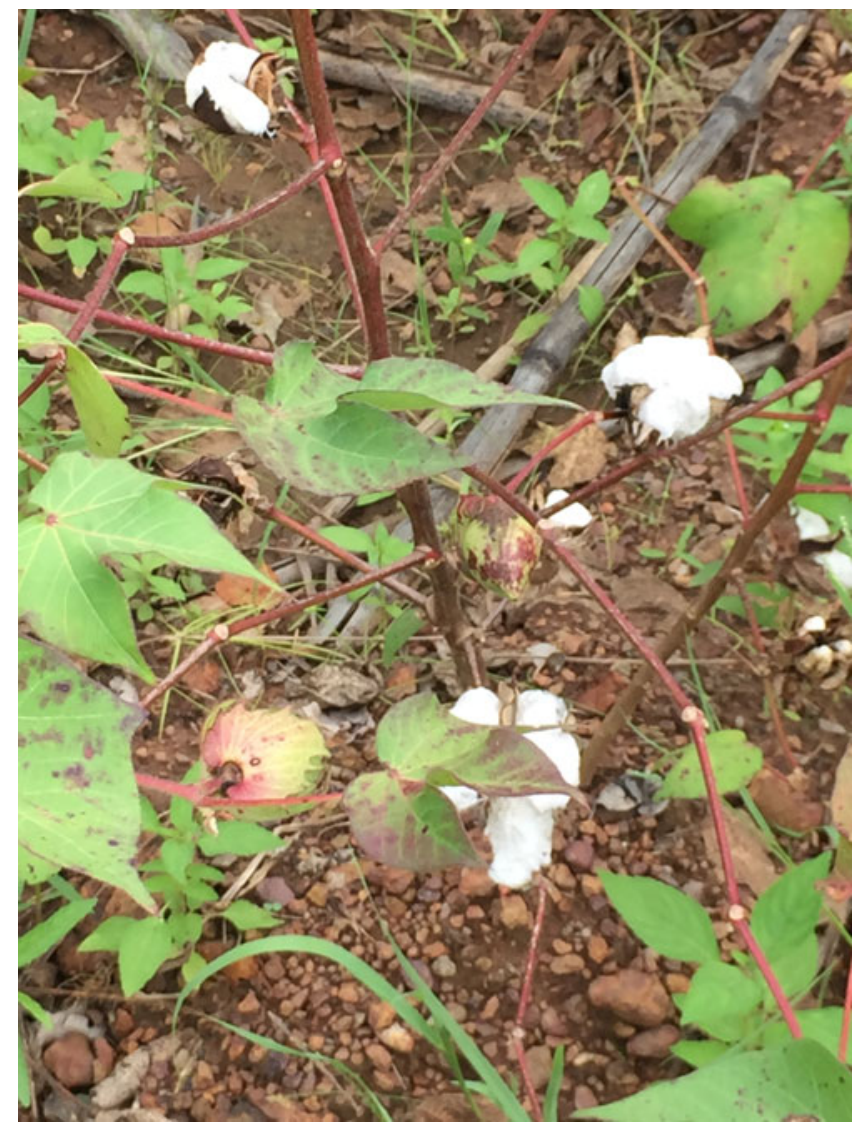

Fig. I Cotton plant. Photograph by the author.

cereals, groundnuts, beans, sesame, and cashew) on other parts. They also do not usually cultivate all their land at the same time, but may leave some areas fallow so the soil can regenerate. Additionally, they may not have the assets and labour at their disposal to cultivate all their land at once. Farmers decide what they will cultivate in view of the soil quality, their household consumption, market factors, and the available assets and labour. Labour is mostly unpaid family labour, such as farmers' wives and children; producers who have some cash and who cultivate larger areas also hire labour on a daily or weekly basis. The main motivation for cotton cultivation is that the filière system provides farmers with access to fertilizer, pesticide, and guaranteed purchase. Yet, farmers have no choice regarding whom they can buy agricultural inputs from and to whom they can sell the cotton: SOFITEX holds the monopoly for both input supply and purchase. 
Contract farming does not exist for cotton in Burkina Faso; farmers cultivate land they hold tenure rights for or own. Access to land and land rights in Burkina Faso are negotiated and regulated through various formal and informal institutions that may overlap, be complementary, or be concurrent. Traditional institutions vary among regions, localities, and ethnic groups; however, traditional chiefs (chefferie traditionnelle) always play a central role. Peasants either have ownership rights defined by traditional institutions and/or codified by formal land titles, or they have tenure rights through traditional institutions. ${ }^{\text {II }}$

Since the 1960 , farmers have been encouraged by the state to organize themselves into village-level cooperatives (groupements villageois, GVs), "which, however, seldom became genuine cooperatives although this was the state's ambition. Peasants joined forces, but rarely resources. The GVs are to a large extent a structure facilitating the work of various extension services." ${ }^{22}$ The cooperatives were in charge of administering credits to the cotton farmers. In order to have access to input supplies and to be able to sell the cotton, every farmer had to be a member of a cooperative (though, as a rule, only male farmers were members; women could only become members in exceptional cases, such as when the husband dies). At the beginning of the season, SOFITEX would sell inputs to the cooperatives on credit (with interest), and after the harvest, it would purchase the cotton at the fixed price. When the cotton was collected at the end of the season, producers would be paid the basic price minus the cost of the inputs they had received on credit at the beginning of the season. At the end of the season, they could potentially get a premium in case the effective export price for cotton at the time exceeded the basic price. If the export price was below the basic price, this deficit was topped up from a fund (fond de lissage) so that the farmers would still be paid the guaranteed price. The fund was topped up in years of high world market prices for cotton. ${ }^{13}$

I I. For more details, see Luigi Arnaldi di Balme and Peter Hochet, Aperçu du cadre juridique et institutionnel de la gestion des ressources naturelles et foncières au Burkina Faso (Ouagadougou and Paris, 20I0); Leslie C. Gray, "Environmental Policy, Land Rights, and Conflict: Rethinking Community Natural Resource Management Programs in Burkina Faso", Environment and Planning D: Society and Space, 20:2 (2002), pp. I67-I 82; Quentin Gausset, "Le foncier et les arbres dans le sud-ouest du Burkina Faso. Présentation de l'approche contractuelle de PETREA”, in Anette Reenberg and Henrik Secher Marcussen (eds), Etablir le lien entre la recherche et la politique: Bridging Research and Policy - Proceedings of the Workshop, 2-3 December 2004 (Ouagadougou, Burkina Faso, 2004); Quentin Gausset, "L'aspect foncier dans les conflits entre autochtones et migrants au sud-ouest du Burkina Faso", Politique africaine, 4 (2008), pp. 52-66. I 2. Lars Engberg Pedersen, "Politics, Development and Custom: People's Struggle for Evasion in Yatenga, Burkina Faso", in Tor Benjaminsen and Christian Lund (eds), Politics, Property and Production in the West African Sabel: Understanding Natural Resources Management (Uppsala, 200I), pp. 75-100, p. 83.

I3. Cornelia Staritz, Susan Newman, Bernhard Tröster, and Leonhard Plank, "Financialization and Global Commodity Chains: Distributional Implications for Cotton in Sub-Saharan Africa”, Development and Change, 49:3 (2018), pp. 81 5-842, p. I 3 . 
More than ninety-five per cent of Burkina Faso's cotton fibre is exported; hence there is very little value created in the country itself. During the "revolutionary" period of Thomas Sankara's presidency (I984-I987), local production - i.e. spinning, weaving, and further processing - was promoted. A national textile factory, Faso Dan Fani, operated in the town of Koudougou. Sankara was well-known for wearing Dan Fani cloth himself and for encouraging members of the government and public servants to do likewise. ${ }^{14}$ However, under pressure from the World Bank to privatize state-owned companies, the governments of Blaise Compaoré, who succeeded Sankara as president (1987-2014), and Prime Minister Kadre Désiré Ouédraogo agreed in 1997 to sell Faso Dan Fani, which was eventually closed in $200 \mathrm{I} .^{15}$

\section{Liberalization from the mid-I990s onwards}

From the mid-I990s onwards, the World Bank pushed the liberalization of the cotton sector in Burkina Faso, as it urged economic liberalization in developing countries in general. The first measure taken to restructure the filière was the reorganization of the GV cooperatives into groupements des producteurs de coton (GPCs) in I 996. Until then, the GVs had been organized strictly at the village level, so all agricultural producers from one village formed one cooperative and had to share credits and inputs. In many cases, farmers complained that they could not rely on others - that others took seeds, fertilizer, and pesticides on credit, charging them to the cooperative's account, but then failed to produce, and those who worked hard ended up having to pay off the debts of others. The GPCs, in contrast, were established on a voluntary basis by cotton producers who trust each other. Often, farmers from the same village are members of different GPCs. Members might be removed from the GPC if they do not follow the rules, and potential members might not even be accepted if they have a bad record. ${ }^{16}$ In general, as compared to former GV cooperatives, the GPCs have far fewer members and are less diverse. ${ }^{17}$ In

I 4. Ernest Harsch, "The Legacies of Thomas Sankara: A Revolutionary Experience in Retrospect", Review of African Political Economy, 40:137 (2013), pp. 358-374, p. 371; Rémy Herrera and Laurent Ilboudo, "Les défis de l'agriculture paysanne. Le cas du Burkina Faso", L'Homme E la Société, I 83-I 84 (20I2), pp. 83-95, p. 88.

I 5. Ernest Harsch, "Burkina Faso in the Winds of Liberalisation", Review of African Political Economy, $25: 78$ (1998), pp. 625-641, p. 631; Mathieu Hilgers, Une ethnographie à l'échelle de la ville. Urbanité, histoire et reconnaissance à Koudongou (Burkina Faso) (Paris, 2009), p. I 23.

r6. Jonathan Kaminski, Derek Headey, and Tanguy Bernard, "The Burkinabè Cotton Story 1992-2007: Sustainable Success or Sub-Saharan Mirage?”, World Development, 39:8 (2011), pp. I460-I 475 , p. I 463.

17. Brian Dowd-Uribe, "Liberalisation Failed: Understanding Persistent State Power in the Burkinabè Cotton Sector from 1990 to 2004", Development Policy Review, 32:5 (2014), pp. $545-566$, p. 558 . 
many cases, more well-off farmers join together in one cooperative, while poorer farmers make up another. Many of the problems that the GVs faced continue to exist after the restructuring, such as problems of internal management, producers ordering more seeds (on credit) than they are able to sow, and difficulties of debt repayment. ${ }^{18}$

In 1998 , the UNPCB was created to be the national organization of cotton farmers. This was not a process initiated "from below" by a broad movement of the cotton farmers themselves. Rather, its creation was, at least partly, a reaction of the authorities to some peasants' attempts to independently organize the cooperatives into an umbrella body (the Fédération Nationale des Organisations Paysannes, or FENOP, created in 1996) meant to represent their interests. ${ }^{19}$ Subsequently, some wealthier producers, together with SOFITEX and the government, pushed the creation of the UNPCB as a more "peaceful", corporatist organization, with the intention of taming the farmers' movement. ${ }^{20}$ The UNPCB is hierarchically structured, with the GPCs being the smallest unit at the local level. The GPCs elect a board at the department level (union départementale) and the departmental boards vote for representatives at the provincial level (union provinciale). Currently, more than 9,000 cooperatives (now formally called the Coopératives simplifiées de production de coton, SCOOPS-PC) exist and are represented by $\mathrm{I} 77$ departmental unions and twenty-eight provincial unions. The provincial unions delegate three representatives each to the general assembly at the national level. The UNPCB's operational bodies at the national level are the administrative council, consisting of twelve members elected by the General Assembly; the Surveillance Council (five members elected by the General Assembly); and technical staff ( 90 employees). The UNPCB is in charge of supporting the producers and providing technical advice to them; representing them in negotiations with the cotton companies and the state authorities; and facilitating the credit system for agricultural inputs, that is, supporting the collection of credits and assuming liability cooperatively. Financially, the UNPCB depends heavily on external donors (such as the French Development Agency and the European Union).

In 1999, the government made the UNPCB become a SOFITEX shareholder, with the aim of increasing "ownership" of the producers in the sector. Initially, the share was thirty per cent, but this was later cut to five per cent.

18. Brian Dowd-Uribe, "Engineering Yields and Inequality? How Institutions and Agro-Ecology Shape Cotton Outcomes in Burkina Faso", Geoforum, 53 (20I4), pp. I6I-I7I, pp. I64-165.

19. Dowd-Uribe, "Liberalisation Failed", p. 557.

20. Ibid., p. 558; Kaminski, Headey, and Tanguy "The Burkinabè Cotton Story 1992-2007", p. 1462. 
In 2004, the government authorized the creation of two fully private cotton companies: Société Cotonnière du Gourma (SOCOMA) and Faso Coton. SOFITEX thus no longer holds the monopoly in the sector; however, the two private companies are much smaller and relatively less important, and more than eighty per cent of production remains under SOFITEX control. The three cotton companies do not compete with each other; rather, the total cotton producing zone is divided among them. SOFITEX controls the west, Faso Coton the centre, and SOCOMA the east. The filière system functions in the same way in all zones, with the UNPCB representing the producer cooperatives and the respective cotton company in charge of supplying seeds, fertilizer, and pesticides on credit to the cooperatives, providing agriculture extensions, and taking care of the purchase, transport, ginning, and sale of the cotton (Figure 2).

In 2006, the Association Interprofessionnelle du Coton du Burkina Faso (AICB) was established as a corporatist agency of the cotton companies, the government, and the UNPCB. Most importantly, it is in charge of fixing the purchase price before the beginning of the season.

\section{COTTON FARMERS’ DISCONTENT AND PROTESTS}

Protests by cotton farmers have occurred frequently since the late 2000s, especially in the SOFITEX zone. It is by far the largest company, and part of the farmers' discontent concerns SOFITEX specifically. The purchase price is a major issue of contention. In addition to demanding higher purchase prices, farmers complain about the poor quality of the seeds, fertilizer, and pesticides they are supplied. Many producers are continuously in debt, and though cotton cultivation does come with risks and challenges, farmers stick to it because it is their only chance to access agricultural assets (input supply, credit, technical support, access to the market). ${ }^{21}$ Many farmers state that they would actually prefer to cultivate maize or other cereals if they could obtain credit to do so. ${ }^{22}$ Cotton farmers can at least get some fertilizer for maize cultivation on credit from the cotton companies if they produce a certain amount of cotton. Farmers also point to problems such as delayed payments after the harvest has been collected and widespread corruption, especially related to the transport and quality classification of the cotton. ${ }^{23}$

21. Dolores Koenig, "Rural Development Is More Than Commodity Production: Cotton in the Farming System of Kita, Mali”, in Moseley and Leslie, Hanging by a Thread, pp. 177-206, p. I 88. 22. Dowd-Uribe, "Engineering yields and inequality?"; FGDs with cotton farmers, Tuy province, 9 February 2019 and 25 September 2019.

23. Dowd-Uribe, "Engineering Yields and Inequality?", pp. I65-166; Gray, "Cotton Production in Burkina Faso", p. 75; Leslie C. Gray and Brian Dowd-Uribe, "A Political Ecology of Socio-Economic Differentiation: Debt, Inputs and Liberalization Reforms in Southwestern Burkina Faso", The Journal of Peasant Studies, 40:4 (2013), pp. 683-702, p. 696; interview with cotton farmers, Dédougou, 26 February 2019. 


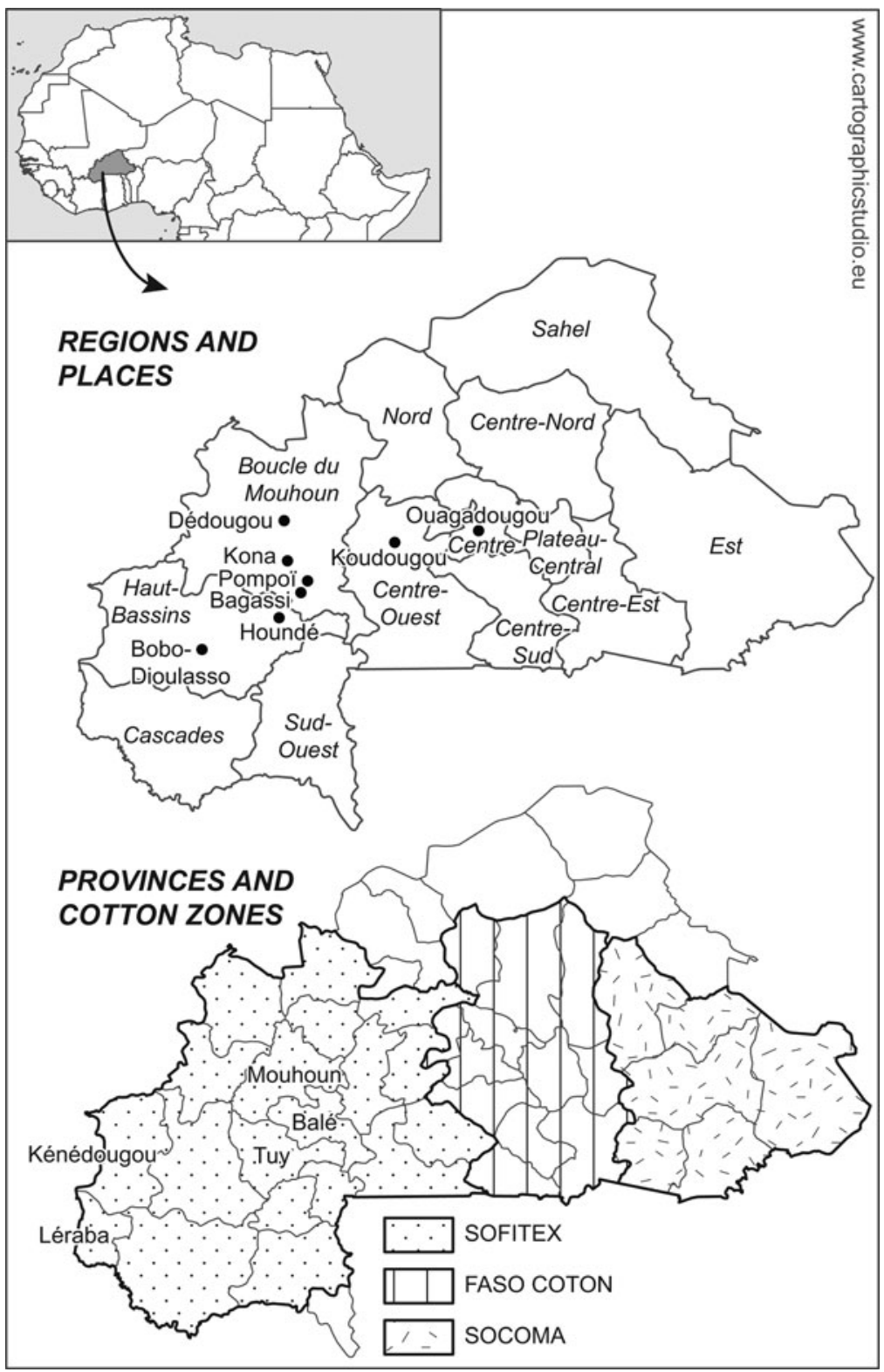

Fig. 2 Cotton production zones in Burkina Faso.

Farmers' protests and conflict over UNPCB leadership in $20 I I$

Protests by cotton producers first occurred in April 20II, the time of year when, after the harvest has been completed, prices for the next season are 
Table I Institutional development of the cotton sector since the I950s.

1950s Development of the sector by the Compagnie Française pour le Développement des Fibres Textiles (CFDT)

1979 Nationalization of the cotton sector: creation of SOFITEX

1980 s Organization of the producers into groupements villageoises (GVs)

1996 Reorganization of the producers into groupements des producteurs de coton (GPCs)

1998 Creation of the Union Nationale des Producteurs du Coton du Burkina (UNPCB)

1999 UNPCB becomes a shareholder in SOFITEX

2004 Authorization for private cotton companies Faso Coton and SOCOMA

2006 Establishment of the Association Interprofessionnelle du Coton du Burkina Faso (AICB)

set. $^{24}$ On 6 April 20I I, a group of cotton farmers in the province of Léraba, in the Cascades region in South West Burkina Faso, marched to the provincial authority (the baut-commissariat) and claimed a balance report covering the last four years and the removal of the agricultural extension service team. ${ }^{25}$ On 27 April, after attending a meeting with the UNPCB and the management of SOFITEX, cotton farmers marched in Bobo-Dioulasso, Burkina Faso's second largest city and the capital of the cotton-producing zone in the southwest. Farmers demanded that the purchase price be raised from 245 CFA francs $(€ 0.32)$ to $500 \mathrm{CFA}$ francs $(€ 0.76)$ per kilo, that the price of fertilizer be reduced to I 5,000 CFA francs ( $€$ 22.87) per kilogram, and that there be fundamental reforms in SOFITEX management, including the dismissal of the company's general director. The protesters declared that they would stage a boycott, refraining from cotton production, if their claims were not met. ${ }^{26}$

The 20I I conflict was entangled with leadership rivalry within the UNPCB. In March 2010, Karim Traoré succeeded François Traoré, ${ }^{27}$ who had been in office since the body was created in I998, as the head of the UNPCB. Karim accused his predecessor of striving to remain in office

24. I am particularly grateful to Ernest Harsch for sharing documentation on the 20 I I protests with me.

25. Mamoudou Traouré, "Plaine aménagée de Douna. Les producteurs mécontents menacent de troubler l'ordre public", Le Pays, 6-8 May 20 II.

26. Une lettre pour Laye, Observateur Paalga, 29 April-ı May 20I I; UNPCB aux marcheurs de Bobo et de Dédougou, “Abandonnez la rue pour vos champs”, Le Pays, i7 May 20 I I.

27. Traoré is a common patronym in Dioula-speaking areas of Western Africa, including Burkina Faso, Mali, and Côte d'Ivoire. Thus, the fact that both Karim and François are named Traoré does not imply that they are related. 
illegitimately; François accused Karim of having been installed by SOFITEX ${ }^{28}$ According to the local press, François Traoré and a couple of other former members of the UNPCB's national board were among those who mobilized the meetings, marches, and petitions in $20 \mathrm{II}^{29}$ Karim Traoré reacted by publicly stating that the demand for a purchase price of 500 CFA francs was "utopian" and "illogical". ${ }^{30}$ This enraged many farmers and spurred marches in Bobo-Dioulasso and Dédougou, another important town in the SOFITEX zone, on I 2 May. ${ }^{3 \mathrm{I}}$ Protesters reiterated their determination to boycott if the government and SOFITEX did not respond to their claims. ${ }^{32}$ In a declaration on 17 May 201 I, the UNPCB condemned the marches and declared itself the "only legal frame of struggle" in the cotton sector. ${ }^{33}$ The UNPCB leadership argued that the farmers were allowing themselves to be made instruments of the members of the former national board. "Leave the streets and go back to your fields", Karim Traoré urged them. ${ }^{34}$

In response, a number of peasants boycotted cotton production in the 20II-20I2 season. ${ }^{35}$ In the province of Kénédougou in the southwest (Haut-Bassins region, bordering Mali), peasants refused to grow cotton and, in July $20 \mathrm{I}$ I, even partly damaged the fields of others who were not participating in the boycott. State security forces intervened violently and arrested "rebel" peasants. Several peasants fled their villages to escape arrest. ${ }^{36}$ One person was killed and numerous others were injured by the security forces; altogether, 225 hectares of cotton crop in the region were destroyed. ${ }^{37} \mathrm{On}$ I 2 July, cotton producers from the rural municipalities of Safané, Bagassi, and Pompoi in the province of Balé, and Kona, in the province of Mouhoun (both located in the Boucle du Mouhoun region in North West Burkina Faso) furiously rushed to the city of Bankuy, armed with machetes, catapults,

28. Ousséni Bance, “Karim Traoré, Président de l’UNPCB. 'Je reconnais avoir milité dans le CDP mais François est dans les instances du MPP’”, lefaso.net, 29 December 2014. Available at: https:// lefaso.net/spip.php?article62517; last accessed I 8 January $202 \mathrm{I}$.

29. Une lettre pour Laye, Observateur Paalga, 29 April-i May 20 I I.

30. UNPCB, "Revendiquer soof cfa par kg de coton graine est utopique", Le Pays, 5 May 20 I I.

3 I. UNPCB aux marcheurs de Bobo et de Dédougou, “Abandonnez la rue pour vos champs”, Le Pays, I7 May $201 \mathrm{I}$.

32. Abdoul Razac Napon, "Crise du coton. Psychose et frustrations dans les zones cotonnières", L'Evènement, I० August $201 \mathrm{I}$.

33. Karim Traoré, "UNPCB aux marcheurs de Bobo et de Dédougou. 'Abandonnez la rue pour vos champs'. Déclaration de l'UNPCB, Bobo-Dioulasso I 3 May 20 I I”, Le Pays, I7 May 201 I. 34. Ibid., my translation.

35. Abdoulaye Tao, "Guerre entre cotonculteurs. Péril sur l'or blanc”, Le Pays, I 2 July, 20 I I.

36. Apollinaire Kam, "Boycott de la campagne cotonnière à N'Dorola. Affrontements entre forces de l'ordre et cotonculteurs”, lefaso.net, is July 20 I. Available at: https://lefaso.net/spip. php?article430I 3 ; last accessed I 8 January 202 I.

37. Thomas J. Bassett, "Capturing the Margins: World Market Prices and Cotton Farmer Incomes in West Africa”, World Development, 59 (2014), pp. 408-42 I, p. 409. 
and other traditional (non-gun) arms, to demand the release of a protester who had been arrested. ${ }^{38}$

The leadership struggle created a severe crisis for the UNPCB. Many farmers felt cheated by the UNPCB and considered Karim Traoré's board a "machine" of SOFITEX. ${ }^{39}$ Traoré managed to temporarily calm tempers by back-pedalling, meeting with the farmers, and declaring their demands were justified..$^{40}$ In 2015 , however, a year in which Burkina Faso underwent a political transition after the fall of long-time President Blaise Compaoré, the cotton farmers' discontent broke out on a large scale once again. They accused Karim Traoré of having supported Compaoré's regime, of abusing the UNPCB's funds to finance activities of the ruling party - Congrès pour la démocratie et le progress (CDP), of which Compaoré was an active member - and of misappropriating funds for other private purposes. Again, farmers threatened boycotts. ${ }^{4 \mathrm{I}}$ On 30 October 2015 , Traoré was arrested and officially

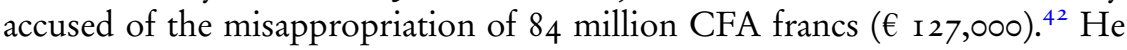
was convicted and spent six months in prison. On 27-28 February 2017, Bambou Bihoun, a wealthy cotton farmer from Tuy province, was elected president of the UNPCB. ${ }^{43}$ Once again, the association is being headed by a moderate president who seeks collaboration with the cotton companies and the government rather than confrontation and conflict.

\section{"Zero cotton": The 2018-2019 boycott campaign}

In recent years, to put forth their demands, farmers from various cooperatives in the SOFITEX zone have set up a network, the Collectif des Paysans, and have begun to organize into a nationwide youth association, ${ }^{44}$ the Organisation Démocratique de la Jeunesse du Burkina Faso (Democratic Youth Organization of Burkina Faso or ODJ). It is not by chance that mobilization has increased in recent years, and cotton production is by no means

38. Serge Coulibaly, “Arrestation d'un Anti-coton”, Le Pays, i 5 -17 July, 20 I I.

39. Napon, "Crise du Coton"; Observateur Paalga, 25 July 20 I I.

40. Tielmè Innocent Kambiré, "Union nationale des producteurs de coton du Burkina. Les cotonculteurs du Kénédougou fument le calumet de la paix", Sidwaya, 3 October 20 i ; Josias Zounzaola Dabiré, "Mesententes entre cotonculteurs. Le calumet de la paix fumé à Kourouma”, Le Pays, 5 October 201 I.

4I. Jessie K. Luna, "The Chain of Exploitation: Intersectional Inequalities, Capital Accumulation, and Resistance in Burkina Faso's Cotton Sector", The Journal of Peasant Studies, 46:7 (2018), pp. I-22, p. II.

42. Rahamatou Sanon, “Arrestation de Karim Traoré. Le conseil de gestion de l'UNPCB mécontent”, Le Pays, 3 November 2015.

43. Romuald Dofini, "Producteurs de coton. Bihoun Bambou est le nouveau président de l'UNPCB", lefaso.net, 28 February 2017. Available at: https://lefaso.net/spip.php?article71 892; last accessed I 8 February $202 \mathrm{I}$.

44. "Youth" in terms of a social category, not necessarily age. 
the only sphere in Burkina Faso that is currently being shaped by intense social mobilization. On 30-3 I October 2014, long-time President Blaise Compaoré was overthrown by a popular insurrection after twenty-seven years in power. The regime change has favoured social mobilization in various social and political fields in the country. The successful mass protests in the capital that led to Compaorés ouster also had a mobilizing effect in the rural provinces. The general mood of "nothing will be as before" gave significant impetus to the mobilizations and has contributed to further strengthening Burkina Faso's vibrant civil society organizations. The ODJ is one of the organizations that was strongly involved in the struggles that eventually resulted in the overthrow of Compaoré. ${ }^{45}$

While the leadership contest within the UNPCB seems, for now, to have been settled, farmers' discontent with the association endures. This was expressed in particular in the hitherto most widespread boycott campaign by Burkinabé cotton farmers in the 2018-2019 season. In the previous season (2017-2018), yields were poor due to unfavourable weather conditions (insufficient rainfall in particular), and - according to the farmers - also due to poorquality fertilizer. In January 2018 , smallholder cotton producers represented by the ODJ held a press conference to complain about the poor quality of fertilizer delivered to them in the SOFITEX zone. They pointed out that the fertilizer contained stones, which, according to them, resulted in significantly lower yields (the cotton harvest starts in December, so by the end of January farmers are able to assess the season's yield). They demanded that farmers who had received inferior quality fertilizer should be compensated. "As the benefits are shared, losses have to be shared, too", a spokesperson of ODJ in Tuy province stated, "The cotton producing farmers must not be left alone to deal with the catastrophic consequence of the season. All actors of the filiere have to bear the costs. Thus, simply cancel the total debts of the cotton season 2017-201 8 due to force majeure." 46

They demanded, moreover, that the quality of the harvested cotton be assessed by independent experts - with neither the UNPCB, nor SOFITEX being involved - and urged farmers to refuse to pay back their credit for the season until the assessment was complete. They accused the UNPCB of not representing the interests of the farmers: "They [the persons responsible at the UNPCB] let us know that they would not put pressure on SOFITEX",

45. For more details, see Bettina Engels, "Political Transition in Burkina Faso", in Hans J. Giessmann and Roger Mac Ginty (eds), How Regimes Change: Post-Conflict Transitions Revisited (Cheltenham, 2018), pp. 223-237; Bettina Engels, "A Stolen Revolution: Popular Class Mobilisation in Burkina Faso", Labor History, 60:2 (2019), pp. I 10-1 25.

46. Irmine Kinda, "Campagne cotonnière. L'ODJ incrimine l'engrais", Burkina24, 30 January 2018. Available at: https://www.burkina24.com/2018/01/30/campagne-cotonniere-lodj-incrimine-lengrais/; last accessed I 8 February 202 I; my translation. 
the spokesperson of the protestors reported. ${ }^{47}$ Suspecting the UNPCB of corruption, the protesters announced that they would address the anti-corruption state authority and the civil society network Réseau national de lutte anti-corruption (National Network for the Fight Against Corruption, or REN-LAC).

On 30 April 20I 8, cotton farmers represented by the ODJ presented their demands to the regional state authority (Gouverneur) of the Haut-Bassins region, complaining that the government had supported SOFITEX and its subcontractors with I4 billion CFA francs (about $€ 2$ I million) but had not compensated the farmers. To back up their demands, the farmers launched a boycott of cotton cultivation. ${ }^{8}$ The initiative to boycott spread rapidly, particularly within the SOFITEX zone, and went beyond the organized groups. The province of Kénédougou was a case in point; in the 2018-2019 season, almost all the farmers there joined the boycott. Even the initial organizers of the boycott campaign were surprised by this. ${ }^{49}$

Boycotts mean that farmers decide not to cultivate cotton at all, or to significantly reduce the area used for cotton cultivation and instead grow cereals (such as maize, millet, and sorghum), beans or cash crops (such as sesame, groundnuts, and cashew). In principle, farmers who decide not to grow cotton are not supposed to take inputs for the season on credit from the respective cotton company. However, as for most farmers cotton cultivation is virtually the only means to gain access to fertilizer, some might have taken fertilizer from the cotton companies and then used it to grow maize or other crops instead. This became a particular problem in cases where there was no consensus within a GPC on whether and to what extent to boycott cotton, as debts are collectivized and at the end of the season the members who have grown cotton will also be held accountable for the credits of those who boycotted it. In most cases, however, farmers within the GPCs did discuss this issue among themselves until they came to an agreement; and if some individuals decided to reduce the surface area they would cultivate, they announced it in advance and thus ordered fewer inputs on credit.

Consent for the boycott campaign varied among farmers, not only regionally - with some provinces showing a higher degree of participation than others - but also within villages, GPCs, and even families. But regardless of whether they supported the boycott in principle, cotton producers widely agreed that a full boycott would be challenging in view of the absence of cash-

47. Herman Frédéric Bassolé, "Campagne cotonnière 2017-2018. Des producteurs dénoncent la mauvaise qualité des engrais”, lefaso.net, 3 I January 20I8. Available at: https://lefaso.net/spip. php?article 81703; last accessed I 8 February 202 I; my translation.

48. ODJ, Conférence de presse des militants paysans de l'ODJ des zones cotonnières (SOFITEX, FASO-COTON et SOCOMA) du Burkina Faso, 28 May 2019. Déclaration liminaire (Ouagadougou, 2019).

49. Informal conversation, Bobo-Dioulasso, 26 September 2019. 
generating alternatives, and because refusing cotton cultivation is particularly difficult for poor farmers who cannot afford fertilizer to grow other crops. Systematic data are lacking on who participated to what extent in the boycott, but it can be assumed that the poorer farmers are, the greater the obstacles to engaging in the boycott - namely the difficulty of refusing to take any inputs at all on credit from the cotton company at the beginning of the season.

Why do farmers boycott cotton cultivation, given that they risk losing a substantial part of their livelihoods? The assumption behind the boycott campaign is, as one of its leaders explained in an interview, ${ }^{50}$ that "if all farmers would produce 'zero cotton', SOFITEX would have to shut down and its managers would lose their salaries". The call to boycott was passed on from person to person, from village to village, promoted by the Collectif des Paysans and local activists within the ODJ. Representatives from the cotton industry confirmed that they were indeed following the spreading calls for a boycott "with concern". ${ }^{\text {I }}$ In any case, the campaign resulted in a significant decrease in cotton production in the 2018-2019 season: while the Burkinabé cotton companies had set a target output of 800,000 tons, only 436,000 tons were produced, a twenty-nine per cent decrease from the previous season. This led to Burkina Faso going from being Africa's largest cotton producing country to fourth-largest, after Benin, Mali, and Côte d'Ivoire. Though weather conditions and the unstable security situation in Burkina Faso also negatively impacted cotton production, all actors involved consider the boycott to be a major cause. ${ }^{52}$

The main demands that farmers raise in their protests include the increase of the purchase price to $500 \mathrm{CFA}$ francs; lower prices for and greater quality control of agricultural inputs; changes to the allocation mechanism for these inputs; and relief of farmers' internal and external debts for the 2017-2018 and 2018-2019 seasons. Key claims also concern the UNPCB: the dissolution of the national and departmental boards; an independent audit of all its offices at the national, departmental and provincial levels; and examination of cases of possible misuse of UNPCB funds and the conviction of all found responsible for it. ${ }^{53}$ A year after they had first presented their claims, protesting farmers went to see the Governor of the Haut-Bassins region again. Stating that the conflict was beyond his authority, he advised the farmers to address the government at the national level. Thus, cotton farmers from the three cottonproducing zones covered by SOFITEX, SOCOMA, and Faso Coton joined

50. Houndé, I4 February 2019; my translation.

5. Interview, Bobo-Dioulasso, 8 February 2019; my translation.

52. Nadoun Coulibaly, "Burkina Faso. La production cotonnière chute de $30 \%$ et dégringole à 436000 tonnes", Jeunes Afrique, i6 April 2019.

53. Issoufou Ouédraogo, “ODJ. Des producteurs menacent de boycotter la culture du coton", lefaso.net, 28 May 2019. Available at: https://lefaso.net/spip.php?article89937; last accessed I 8 February $202 \mathrm{I}$. 
forces and held a workshop in Ouagadougou on I6-I7 March 20I9. They agreed on some major demands, which they submitted on 27 May to the Ministry of Agriculture and Water. ${ }^{54}$

Farmers also expressed their dissatisfaction with the UNPCB by withholding their union dues, which add up to 750 CFA francs ( $€$ I.I4) per ton of cotton that a cooperative sells: of which 250 CFA francs each goes to the departmental, provincial, and national levels. "These guys don't do their work", the farmers explained, "We refuse the payment of the contributions because the union does not represent our interests. [...] And we do not understand what happens with the money." 55 Moreover, farmers stayed away from meetings, disregarded recommendations by SOFITEX agents, and bought or sold inputs on the local markets, thus sidestepping SOFITEX altogether. ${ }^{56}$

\section{The UNPCB as an issue of discontent}

Many studies, primarily by the World Bank, portray the integration of producers - in this case, of the UNPCB - into the governance institutions of the cotton sector as a success of liberalization policies. This largely reflects the idea of "participation" that has been introduced as an integral element of "new" modes of liberal economic governance since the r990s. Participation of various stakeholders is created in a top-down model that determines and limits, a priori, precisely who is supposed to participate in what ways and in which arenas, with the aim of making governance more effective. However, who the stakeholders actually are, and whose interests can and should be represented by whom and in which way are matters that can be contested. The UNPCB, since its creation, has been substantially influenced by SOFITEX and the government, and both have steadily and successfully hindered more critical or radical farmers from gaining influence or taking up any responsibilities or posts within the union. From the local to the national level, the UNPCB is entangled with the authorities and political parties: with the CDP, Compaorés ruling party, until he was overthrown in 2014, and since then with its successor, the Movement pour le Peuple et le Progrès (MPP). The links between the authorities and the UNPCB became particularly obvious in 2013 and 20I4, when, related to the fall of Compaoré, then-president of the UNPCB Karim Traoré, who was close to the ruling elite, was also overthrown.

Moreover, posts within the UNPCB are mostly occupied by wealthy producers (rich and middle-class farmers) who have significant amounts of land, equipment, and access to (often unpaid family) labour. The current president

54. ODJ, "Conférence de presse des militants paysans".

55. FGD with cotton farmers, village in Tuy province, 25 September 2019, my translation.

56. Luna, "The chain of exploitation", p. I I. 
of the union is one of the richest cotton farmers in the country, cultivating a very large area relative to the vast majority of the smallholders and even most middle-class farmers in the sector. Karim Traore is likewise among the richest cotton farmers in the country. By contrast, the majority of cotton producers have rather small land holdings and insufficient access to the necessary means of production and labour. These farmers produce a maximum of one ton of cotton per hectare each season, often less, and struggle to repay their debts. ${ }^{57}$ Those who benefit substantially from cotton production are a minority of larger farmers and "actors employed higher up the cotton commodity chain [...] including cotton company employees, state actors, agribusiness, banks, textile manufacturers, and end consumers of cotton products". ${ }^{58}$

It would be misleading to consider the UNPCB a genuine representative of cotton farmers as a whole. A significant share of the producers feel substantially unsatisfied with the UNPCB. ${ }^{99}$ Many farmers feel the UNPCB is hindering them in putting their demands forward rather than representing them. They complain that they cannot raise claims directly with the respective cotton companies or the authorities, but must address them to the UNPCB, since the companies and the authorities negotiate exclusively with the UNPCB.

\section{CONCLUSION}

The policies of economic liberalization, as promoted by the World Bank since the mid-I990s, have affected Burkinabé cotton farmers with regard to how they are organized: there was a shift in the cooperative system from the GVs to the GPCs, which are required to be incorporated into the hierarchical structure of the UNPCB. This change in the institutional setting also implies a change in the modalities of wielding power in the sector: the state authorities and SOFITEX remain the principal powerful actors, but since the creation of the UNPCB they now exercise even more control over the sector indirectly through the union.

The way liberalization was implemented strengthened rather than weakened the control and influence of the state in the sector. So, instead of a relative loss of state control over the economy, there has rather been a shift towards a mode of indirect private governance, where the state exercises control through

57. Alain Bonnassieux, "Filière cotton, emergence des organisations de producteurs et transformations territoriales au Mali et au Burkina Faso", Les Cahiers d'Outre-Mer, 55:220 (2002), pp. 42 I-434; FGD with cotton farmers, Tuy Province, 7 February 2019.

58. Jessie K. Luna, "Getting Out of the Dirt: Racialized Modernity and Environmental Inequality in the Cotton Sector of Burkina Faso", Environmental Sociology, 4:2 (2018), pp. 22 I-234, p. 22 I. 59. Dowd-Uribe, "Engineering yields and inequality?", p. I66; FGDs with cotton farmers, Tuy province, 9 February 2019, 25 September 2019, 26 September 2019, and 3 October 2019, and Mouhoun province, 26 February 2019 ; interview with cotton farmer, Houndé, I4 February 2019. 
allegedly private actors (SOFITEX) - which may result in the modes of control becoming more difficult to see through for some actors, such as smallholders. Liberalization implies a shift in power, from labour - and, with respect to agriculture, from smallholder producers - to the merchants. In the case of the cotton sector, this means more power has gone to SOFITEX. As SOFITEX is state-owned, liberalization thus led to a higher degree of centralization of power in the cotton sector. For the farmers, the maintenance of the filière system implies that they are less exposed to the vagaries of the global market, as well as to instabilities in the price and availability of inputs, and to fluctuations in the purchase price.

The creation of the UNPCB was a core element of the reform of the sector, that is, the way in which the Burkinabé state implemented the demand for liberalization by external actors. Policymakers, representatives of state authorities, the World Bank and other donor agencies, the cotton industry, and the UNPCB itself all claim that the union was created to strengthen the position of farmers and to include them in the governance of the sector. However, from the perspective of many smallholder producers (particularly the poorer ones), the UNPCB weakens their position and instead sustains the interests of SOFITEX, the rich producers, and the state. Therefore, while the farmers' discontent is now, as before, directed at the authorities and SOFITEX, the UNPCB leadership has become an additional target of anger.

The UNPCB was intentionally created as a corporatist institution whose interaction with the authorities and the cotton companies is supposed to be collaborative and highly institutionalized. In this sense, it serves more to tame and control the farmers than to represent their interests in potential confrontations with the cotton companies and the state. Indeed, SOFITEX has been, and probably still is, strongly involved in ousting more radical farmers from the UNPCB and replacing them with moderate ones in positions of responsibility in the union.

It is worth noting that liberalization and structural adjustment policies as such are not so much at the centre stage of the farmers' mobilizations; protests are rather triggered by quite concrete issues such as the purchase price and the quality of seeds and fertilizer. It can be argued, of course, that these issues result from economic liberalization. However, it remains open to interpretation whether the protests can be framed as farmer resistance to liberalization and structural adjustment. In any case, since liberalization, the producers' very means of organizing, notably the UNPCB itself, have become fields of contestation in their own right. The various resistance efforts of the cotton farmers, including their refusal to pay their dues to the UNPCB and the boycott, are related to the effects of the way the sector is structured. Economic liberalization has substantially impacted the institutional setting within the sector and changed the rules of the game, affecting the conditions and mechanisms by which interests can be articulated and negotiated. It is these rules that are centre stage in the recent conflicts. 